\title{
Proteinuria in Patients with Solid Tumors Treated with Ramucirumab: A Systematic Review and Meta-Analysis
}

\author{
Omar Abdel-Rahman Hesham ElHalawani \\ Clinical Oncology Department, Faculty of Medicine, Ain Shams University, Cairo, Egypt
}

\section{Key Words}

Ramucirumab · Proteinuria · Renal impairment

\begin{abstract}
Background: We performed a systematic review and metaanalysis of the risk of proteinuria associated with ramucirumab. Methods: Eligible studies included randomized phase II and III trials of patients with solid tumors on ramucirumab, describing events of all-grade and high-grade proteinuria. Results: Our search strategy yielded 170 potentially relevant citations from PubMed/Medline, CENTRAL Cochrane database, ASCO and ESMO meeting libraries. After exclusion of ineligible studies, a total of 11 clinical trials were considered eligible for the meta-analysis. The relative risk (RR) of allgrade proteinuria was 3.31 (95\% Cl 2.48-4.42; $\mathrm{p}<0.00001)$. Moreover, the RR of high-grade proteinuria was $5.28(95 \% \mathrm{Cl}$ $2.32-12.01 ; p<0.0001)$. Conclusions: Our meta-analysis has demonstrated that ramucirumab use is associated with an increased risk of all-grade and high-grade proteinuria. Early detection strategies should be employed in those patients to prevent the progression to more sinister renal disease.
\end{abstract}

c 2015 S. Karger AG, Basel

\section{Introduction}

Ramucirumab is a monoclonal antibody that works by binding to vascular endothelial growth factor receptor-2 (VEGFR-2) and hence blocking the proangiogenic effects of VEGF signaling $[1,2]$. This blocking of the tumor neoangiogenesis should ultimately slow down tumor growth [3].

Ramucirumab has been FDA approved for the treatment of advanced gastric cancer in the second-line setting both as a monotherapy and in combination with paclitaxel $[4,5]$. Different ramucirumab-based combinations have also been FDA approved for second-line treatment of advanced nonsmall cell lung cancer and metastatic colorectal cancer. Additionally, a number of ongoing studies are evaluating this agent in multiple indications for solid tumors.

Most antiangiogenic agents - including ramucirumab - may cause some characteristic adverse effects, including some cardiovascular, gastrointestinal and hematological toxicities [6, 7]. Moreover, renal toxicities (particularly asymptomatic proteinuria) are common in patients treated with antiangiogenic agents [8]. Because of the small number of patients with renal toxicities in each ramucirumab study, the overall risk of renal toxicities with ramucirumab may not be clear. Thus, we conducted a systematic review and meta-analysis of available

\section{KARGER}

E-Mail karger@karger.com

www.karger.com/che
(C) 2015 S. Karger AG, Basel

0009-3157/15/0606-0325\$39.50/0
Dr. Omar Abdel-Rahman

Clinical Oncology Department

Faculty of Medicine, Ain Shams University

Lotfy Elsayed Street, Cairo 11665 (Egypt)

E-Mail omar.abdelrhman@ med.asu.edu.eg 
Fig. 1. Flowchart of study selection proce-

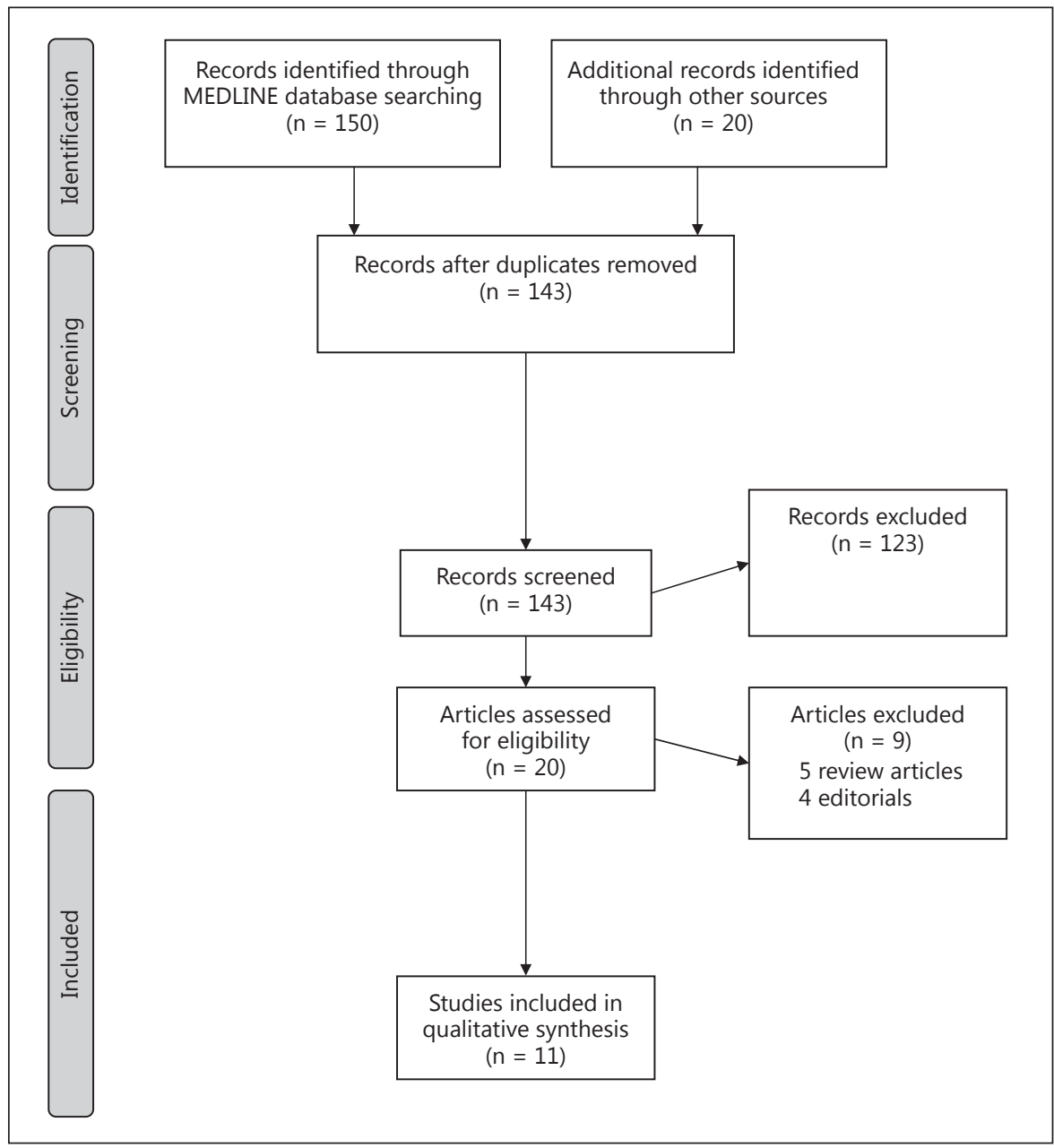
dure.

randomized controlled trials (RCTs) to determine the overall risk of proteinuria in patients with solid tumors treated with ramucirumab.

\section{Methods}

\section{Data Source}

We conducted a literature review of the major databases, including Medline, Cochrane and Google Scholar databases from February 1966 to May 2015 using 'ramucirumab' as a search keyword. The search was limited to RCTs involving human solid tumor patients that were published in English. We also searched abstracts containing the same search keyword from the American Society of Clinical Oncology (ASCO) and European Society of Medical Oncology (ESMO) meetings. We performed and systemically reviewed the meta-analysis according to the Preferred Reporting Items for Systematic Reviews and Meta-Analyses (PRISMA) statement [9].

\section{Study Selection}

Clinical trials that fulfilled the following criteria were included: (1) RCTs in patients with solid tumors, (2) participants allocated to treatment with ramucirumab-based treatment versus control and (3) events and sample size available for proteinuria. For incidence analysis and relative risk analysis, we included RCTs that randomly assigned participants to either ramucirumab-based treatment versus placebo or control treatment.

Meeting abstracts without subsequent full-text publication were excluded. Phase I studies were also excluded because of different dose ranges used. Independent review authors (O.A.-R. and H.E.) checked reports that included the search term by their titles and abstracts for relevance. Then, full texts of the relevant articles were assessed to evaluate eligibility.

\section{Data Extraction and Clinical End Points}

Two review authors (O.A.-R. and H.E.) independently conducted data extraction. The following information was recorded for each study: first author's name, year of publication, trial phase, underlying cancer, treatment regimens, number of patients available for analysis, and number of reported events of all-grade and high-grade proteinuria. 
Table 1. Baseline characteristics of included studies and relevant all-grade (grades 1-4) and high-grade (grades 3-4) toxicities

\begin{tabular}{|c|c|c|c|c|c|c|c|c|}
\hline Study & Phase & Diagnosis & Treatment regimens & $\begin{array}{l}\text { Number } \\
\text { of patients }\end{array}$ & $\begin{array}{l}\text { Protein- } \\
\text { uria }\end{array}$ & $\begin{array}{l}\text { Renal } \\
\text { failure }\end{array}$ & $\begin{array}{l}\text { High-grade } \\
\text { proteinuria }\end{array}$ & $\begin{array}{l}\text { High- } \\
\text { grade } \\
\text { renal } \\
\text { failure }\end{array}$ \\
\hline $\begin{array}{l}\text { Yardley } \\
\text { et al. } \\
{[12], 2014}\end{array}$ & Phase II & $\begin{array}{l}\text { Unresectable, } \\
\text { locally recurrent } \\
\text { or metastatic } \\
\text { breast cancer }\end{array}$ & $\begin{array}{l}\text { Arm A: ramucirumab plus } \\
\text { erbulin } \\
\text { Arm B: erbulin } \\
\text { monotherapy }\end{array}$ & $\begin{array}{l}\text { Arm A: } 69 \\
\text { Arm B: } 65\end{array}$ & $\begin{array}{l}4(5.8 \%) \\
\text { vs. } \\
3(4.6 \%)\end{array}$ & $\begin{array}{l}1 \text { patient } \\
(1.4 \%) \text { in } \\
\text { arm A only }\end{array}$ & $\mathrm{N} / \mathrm{R}$ & $\mathrm{N} / \mathrm{R}$ \\
\hline $\begin{array}{l}\text { Doebele } \\
\text { et al. } \\
{[14], 2015}\end{array}$ & $\begin{array}{l}\text { Randomized } \\
\text { phase II }\end{array}$ & $\begin{array}{l}\text { First-line therapy } \\
\text { in patients with } \\
\text { nonsquamous, } \\
\text { advanced/ } \\
\text { metastatic } \\
\text { nonsmall cell lung } \\
\text { cancer }\end{array}$ & $\begin{array}{l}\text { Arm A: ramucirumab } \\
(10 \mathrm{mg} / \mathrm{kg}) \text { plus pemetrexed } \\
\text { and carboplatin or cisplatin } \\
\text { Arm B: pemetrexed and } \\
\text { carboplatin or cisplatin }\end{array}$ & $\begin{array}{l}\text { Arm A: } 67 \\
\text { Arm B: } 69\end{array}$ & $\begin{array}{l}4(6 \%) \\
\text { vs. } \\
3(4.3 \%)\end{array}$ & $\begin{array}{l}1 \text { patient } \\
(1.5 \%) \text { in the } \\
\text { control arm } \\
\text { only }\end{array}$ & $\begin{array}{l}1 \text { patient } \\
(1.5 \%) \text { in arm } \\
\text { A only }\end{array}$ & $\mathrm{N} / \mathrm{R}$ \\
\hline $\begin{array}{l}\text { NCT01160744 } \\
{[15], 2014} \\
\text { (data of the } \\
\text { squamous } \\
\text { group) }\end{array}$ & $\begin{array}{l}\text { Randomized } \\
\text { phase II }\end{array}$ & $\begin{array}{l}\text { First-line therapy } \\
\text { in patients with } \\
\text { squamous, } \\
\text { advanced/ } \\
\text { metastatic } \\
\text { nonsmall cell lung } \\
\text { cancer }\end{array}$ & $\begin{array}{l}\text { Arm A: ramucirumab } \\
(10 \mathrm{mg} / \mathrm{kg}) \text { plus } \\
\text { gemcitabine and carboplatin } \\
\text { or cisplatin } \\
\text { Arm B: gemcitabine and } \\
\text { carboplatin or cisplatin }\end{array}$ & $\begin{array}{l}\text { Arm A: } 71 \\
\text { Arm B: } 63\end{array}$ & $\begin{array}{l}8(11.3 \%) \\
\text { vs. } \\
1(1.6 \%)\end{array}$ & $\begin{array}{l}\text { None in } \\
\text { either arm }\end{array}$ & $\mathrm{N} / \mathrm{R}$ & $\mathrm{N} / \mathrm{R}$ \\
\hline $\begin{array}{l}\text { Zhu } \\
\text { et al. } \\
{[16], 2014}\end{array}$ & Phase III & $\begin{array}{l}\text { Advanced } \\
\text { hepatocellular } \\
\text { carcinoma, } \\
\text { following first- } \\
\text { line therapy with } \\
\text { sorafenib }\end{array}$ & $\begin{array}{l}\text { Arm A: ramucirumab } \\
(8 \mathrm{mg} / \mathrm{kg}) \text { every } 2 \text { weeks per } \\
\text { cycle and best supportive } \\
\text { care } \\
\text { Arm B: placebo and best } \\
\text { supportive care }\end{array}$ & $\begin{array}{l}\text { Arm A: } 277 \\
\text { Arm B: } 276\end{array}$ & $\begin{array}{l}48(17 \%) \\
\text { vs. } \\
13(5 \%)\end{array}$ & $\begin{array}{l}20(7 \%) \\
\text { vs. } 18(7 \%)\end{array}$ & $\begin{array}{l}6(2 \%) \text { in the } \\
\text { ramucirumab } \\
\text { arm only }\end{array}$ & $\begin{array}{l}6(2 \%) \\
\text { vs. } \\
3(1 \%)\end{array}$ \\
\hline $\begin{array}{l}\text { Wilke } \\
\text { et al. } \\
{[4], 2014}\end{array}$ & Phase III & $\begin{array}{l}\text { Advanced gastric } \\
\text { or } \\
\text { gastroesophageal } \\
\text { junction } \\
\text { adenocarcinoma, } \\
\text { with progression } \\
\text { after first-line } \\
\text { chemotherapy }\end{array}$ & $\begin{array}{l}\text { Arm A: ramucirumab } \\
8 \mathrm{mg} / \mathrm{kg} \text { i.v. on days } 1 \mathrm{and} \\
15 \text {, plus paclitaxel } 80 \mathrm{mg} / \mathrm{m}^{2} \\
\text { i.v. on days } 1,8 \text { and } 15 \mathrm{of} \mathrm{a} \\
28 \text {-day cycle } \\
\text { Arm B: placebo i.v. on days } \\
1 \text { and } 15 \text {, plus paclitaxel } \\
80 \mathrm{mg} / \mathrm{m}^{2} \text { i.v. on days } 1,8 \\
\text { and } 15 \text { of a } \\
28 \text {-day cycle }\end{array}$ & $\begin{array}{l}\text { Arm A: } 327 \\
\text { Arm B: } 329\end{array}$ & $\begin{array}{l}55(16.8 \%) \\
\text { vs. } \\
20(6.1 \%)\end{array}$ & $\begin{array}{l}22(6.7 \%) \\
\text { vs. } \\
14(4.3 \%)\end{array}$ & $\begin{array}{l}4 \text { patients } \\
(1 \%) \text { in the } \\
\text { ramucirumab } \\
\text { arm only }\end{array}$ & $\begin{array}{l}6(1.8 \%) \\
\text { vs. } \\
3(1 \%)\end{array}$ \\
\hline $\begin{array}{l}\text { Fuchs } \\
\text { et al. } \\
{[5], 2014}\end{array}$ & Phase III & $\begin{array}{l}\text { Advanced gastric } \\
\text { or } \\
\text { gastroesophageal } \\
\text { junction } \\
\text { adenocarcinoma }\end{array}$ & $\begin{array}{l}\text { Arm A: ramucirumab } \\
8 \mathrm{mg} / \mathrm{kg} \text { plus best } \\
\text { supportive care } \\
\text { Arm B: placebo plus best } \\
\text { supportive care }\end{array}$ & $\begin{array}{l}\text { Arm A: } 236 \\
\text { Arm B: } 115\end{array}$ & $\begin{array}{l}7(3 \%) \\
\text { vs. } \\
3(3 \%)\end{array}$ & $\mathrm{N} / \mathrm{R}$ & $\begin{array}{l}1 \text { patient } \\
(<1 \%) \text { in the } \\
\text { ramucirumab } \\
\text { arm only }\end{array}$ & $\mathrm{N} / \mathrm{R}$ \\
\hline
\end{tabular}


Table 1 (continued)

\begin{tabular}{|c|c|c|c|c|c|c|c|c|}
\hline Study & Phase & Diagnosis & Treatment regimens & $\begin{array}{l}\text { Number } \\
\text { of patients }\end{array}$ & $\begin{array}{l}\text { Protein- } \\
\text { uria }\end{array}$ & $\begin{array}{l}\text { Renal } \\
\text { failure }\end{array}$ & $\begin{array}{l}\text { High-grade } \\
\text { proteinuria }\end{array}$ & $\begin{array}{l}\text { High- } \\
\text { grade } \\
\text { renal } \\
\text { failure }\end{array}$ \\
\hline $\begin{array}{l}\text { Hussain } \\
\text { et al. } \\
{[18], 2012}\end{array}$ & $\begin{array}{l}\text { Randomized } \\
\text { phase II }\end{array}$ & $\begin{array}{l}\text { Metastatic } \\
\text { castrate-resistant } \\
\text { prostate cancer }\end{array}$ & $\begin{array}{l}\text { Mitoxantrone + prednisone } \\
\text { and randomized to either: } \\
\text { Arm A: ramucirumab } \\
6 \mathrm{mg} / \mathrm{kg} \text { i.v. every week or } \\
\text { Arm B: cixutumumab } 6 \mathrm{mg} / \\
\text { kg i.v. every week }\end{array}$ & $\begin{array}{l}\text { Arm A: } 66 \\
\text { Arm B: } 66\end{array}$ & $\begin{array}{l}10(15.2 \%) \\
\text { vs. } \\
4(6.1 \%)\end{array}$ & $\begin{array}{l}1(1.5 \%) \\
\text { vs. } \\
2(3 \%)\end{array}$ & $\mathrm{N} / \mathrm{R}$ & $\mathrm{N} / \mathrm{R}$ \\
\hline
\end{tabular}

NCT01160744: the NCT01160744 study includes 2 subgroups: a nonsquamous group (published as Doebele et al. [14], abstract) and a squamous group whose data has not yet been published and the above toxicity data are extracted from clinicaltrials.gov records [15]. N/R = Not reported.

Any discrepancies between review authors were solved by consensus. The number of patients evaluable for toxicity was utilized as the number analyzed for each study. In the included clinical trials, relevant adverse events were recorded according to the Common Toxicity Criteria of Adverse Events (CTCAE) version 3.0 or 4.0 , which are quite similar in terms of grading these adverse events.

\section{Statistical Analyses}

The principal summary measures were relative risk (RR) and corresponding 95\% CIs of all-grade (grades 1-4) and high-grade (grades 3-4) proteinuria. For all calculations of RRs and CIs, we have used data extracted only from the included RCTs, comparing the incidence of each adverse event in patients assigned to ramucirumab-based treatment with those assigned to control treatment in the same trial. To calculate 95\% CIs, the variance of a log-transformed study-specific RR was derived using the delta method. Statistical heterogeneity in results between studies included in the analysis was assessed through Cochrane's Q statistic and inconsistency was quantified through $\mathrm{I}^{2}$ statistic. The assumption of homogeneity was not considered for $\mathrm{p}$ values $<0.10$. RRs were calculated using random- or fixed-effects models, depending on the heterogeneity of included studies. When substantial heterogeneity was not found, the pooled estimate calculated based on the fixed-effects model was reported using the inverse variance method. When substantial heterogeneity was found, the pooled estimate calculated based on the random-effects model was reported using the DerSimonian method, which considers both within-study and between-study variations $[10,11]$. Statistical analyses were performed by using the program Review Manager (RevMan) 5.3 (Copenhagen, Denmark).

\section{Results}

\section{Search Results}

Our literature search revealed 170 potentially relevant publications on ramucirumab. The reasons for study exclusion are illustrated in figure 1 . Altogether, a total of 11 primary studies met the inclusion criteria, including 6 phase III trials and 5 phase II trials. Underlying solid tumors included advanced gastric cancer in 3 studies, advanced nonsmall cell lung cancer in 3 studies, metastatic breast cancer in 2 studies, castrate resistant prostate cancer in 1 study, metastatic colorectal cancer in 1 study, and advanced hepatocellular carcinoma in 1 study. All included trials generated randomized treatment allocation sequences. Overall, a total of 5,694 patients were included in this analysis. The baseline characteristics and the number of relevant adverse events in each trial are presented in table 1 . The relevant adverse events were not consistently reported in all trials.

\section{Overall Incidence of the Relevant Adverse Events}

A total of 3,103 patients (representing the ramucirumab-containing arms of the included studies) were evaluated in the incidence analysis. All-grade proteinuria was reported in 10 studies and it ranged from 5.8 to $17 \%$. 


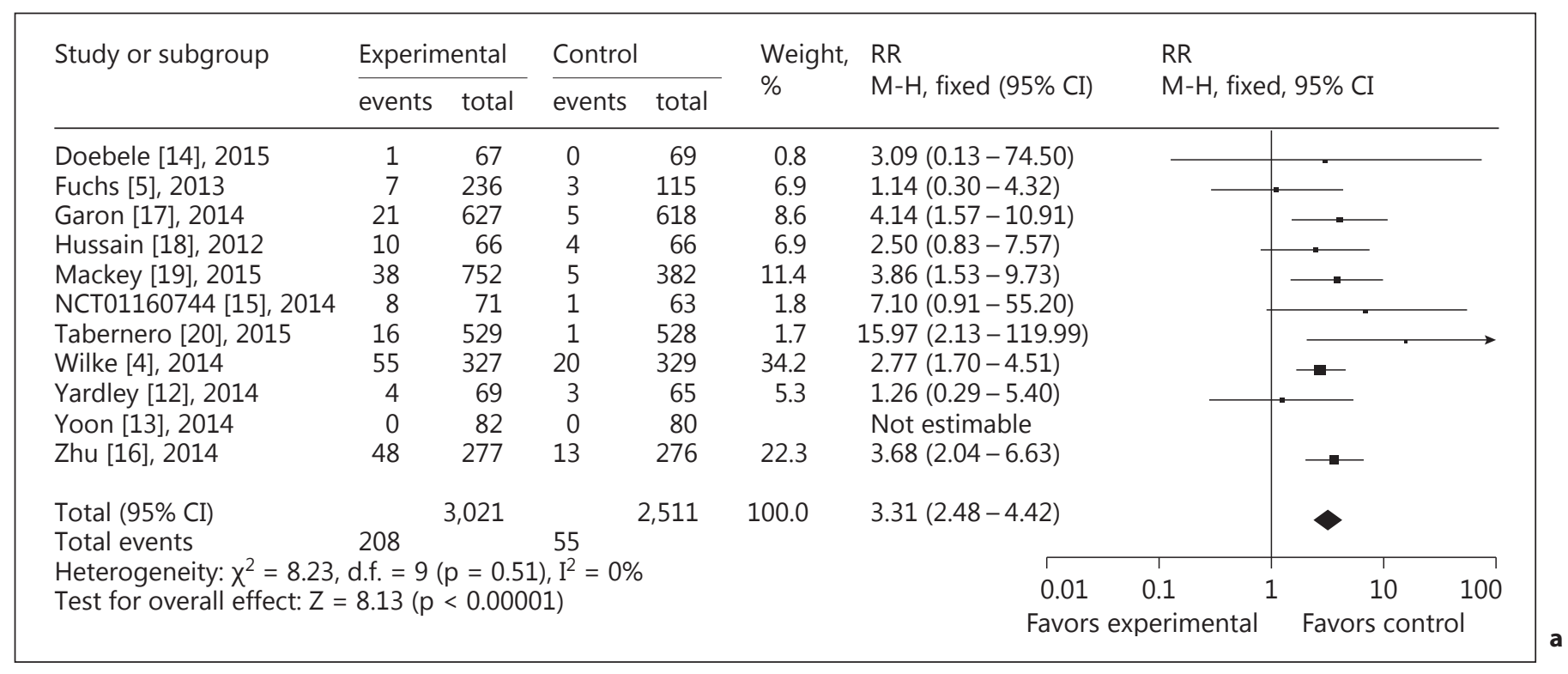

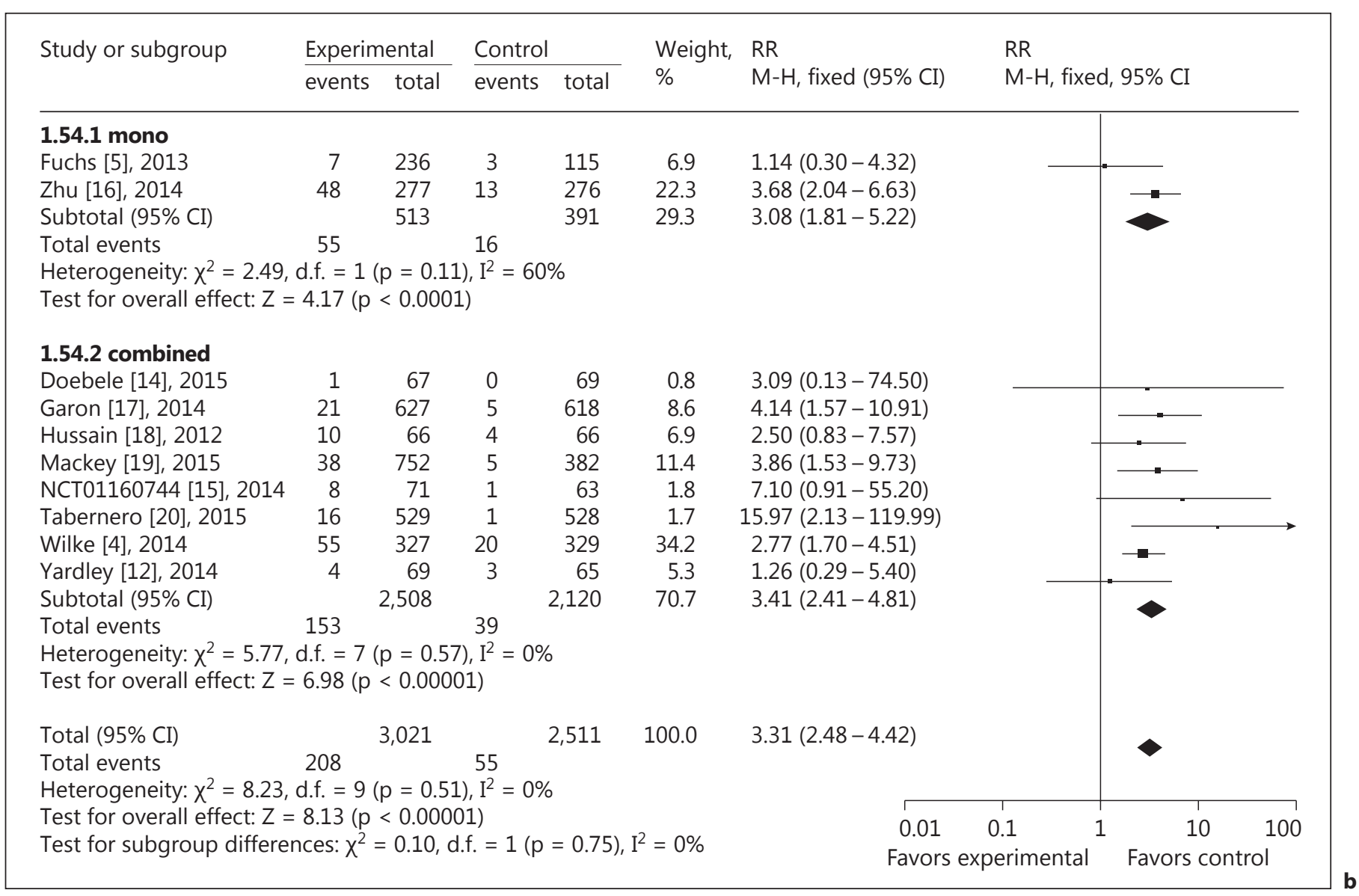

Fig. 2. a Forest plots of RR of all-grade proteinuria associated with ramucirumab vs. control. b Subgroup analysis of proteinuria according to treatment type (monotherapy vs. combination); the size of squares corresponds to the weight of the study in the meta-analysis. $\mathrm{M}-\mathrm{H}=$ Mantel-Haenszel method. 


\begin{tabular}{|c|c|c|c|c|c|c|c|c|}
\hline \multirow[t]{2}{*}{ Study or subgroup } & \multicolumn{2}{|c|}{ Experimental } & \multicolumn{2}{|c|}{ Control } & \multirow{2}{*}{$\begin{array}{l}\text { Weight, } \\
\%\end{array}$} & \multirow{2}{*}{$\begin{array}{l}\text { RR } \\
M-H \text {, fixed }(95 \% \mathrm{CI})\end{array}$} & \multirow{2}{*}{\multicolumn{2}{|c|}{$\begin{array}{l}\text { RR } \\
M-H \text {, fixed, } 95 \% \mathrm{CI}\end{array}$}} \\
\hline & events & total & events & total & & & & \\
\hline Doebele [14], 2015 & 4 & 67 & 3 & 69 & 43.5 & $1.37(0.32-5.91)$ & & $\square$ \\
\hline Fuchs [5], 2013 & 1 & 236 & 0 & 115 & 9.9 & $1.47(0.06-35.77)$ & & \\
\hline Garon [17], 2014 & 1 & 627 & 0 & 618 & 7.4 & $2.96(0.12-72.45)$ & & \\
\hline Hussain [18], 2012 & 0 & 66 & 0 & 66 & & Not estimable & & \\
\hline Mackey [19], 2015 & 3 & 752 & 0 & 382 & 9.8 & $3.56(0.18-68.75)$ & & \\
\hline NCT01160744 [15], 2014 & 0 & 71 & 0 & 63 & & Not estimable & & \\
\hline Tabernero [20], 2015 & 16 & 529 & 1 & 528 & 14.7 & $15.97(2.13-119.99)$ & & \\
\hline Wilke [4], 2014 & 4 & 327 & 0 & 329 & 7.3 & $9.05(0.49-167.51)$ & & \\
\hline Yardley [12], 2014 & 0 & 69 & 0 & 65 & & Not estimable & & \\
\hline Yoon [13], 2014 & 0 & 82 & 0 & 80 & & Not estimable & & \\
\hline Zhu [16], 2014 & 6 & 277 & 0 & 276 & 7.4 & $12.95(0.73-228.83)$ & & \\
\hline Total $(95 \%$ CI) & & 2,815 & & 2,317 & 100.0 & $5.28(2.32-12.01)$ & & \\
\hline & 35 & & 4 & & & & & \\
\hline \multirow{2}{*}{\multicolumn{5}{|c|}{$\begin{array}{l}\text { Heterogeneity: } x^{2}=5.75, \text { d.f. }=6(p=0.45), I^{2}=0 \% \\
\text { Test for overall effect: } Z=3.97(p<0.0001)\end{array}$}} & & 0.01 & $0.1 \quad 1$ & $10 \quad 100$ \\
\hline & & & & & \multicolumn{3}{|c|}{ Favors experimental } & Favors control \\
\hline
\end{tabular}

Fig. 3. Forest plots of RR of high-grade proteinuria associated with ramucirumab vs. control. $\mathrm{M}-\mathrm{H}=\mathrm{Mantel}-$ Haenszel method.

\section{Relative Risk of All-Grade and High-Grade Relevant} Adverse Events

In order to determine the specific contribution of ramucirumab to the development of proteinuria, a metaanalysis of the RR of proteinuria was performed on the assessed randomized trials and it showed that the RR of all-grade proteinuria was 3.31 (95\% CI 2.48-4.42; p < 0.00001 ; fig. 2a). Moroever, the RR of high-grade proteinuria was 5.28 (95\% CI 2.32-12.01; $<<0.0001$; fig. 3). Thus, patients treated with ramucirumab have an increased risk of all-grade and high-grade proteinuria. The fixed-effects model was used for all the evaluated toxicities. Funnel plot analysis revealed no evidence of a publication bias (fig. 4).

\section{Subgroup Analysis}

We conducted a subgroup analysis for the risk of proteinuria according to the type of treatment (ramucirumab monotherapy vs. ramucirumab-based combination) and we found no evidence of a statistically significant difference between the subgroups.

\section{Discussion}

To the best of our knowledge, this is the most updated meta-analysis providing an evaluation of the incidence and risk of proteinuria in patients with solid tumors treat-

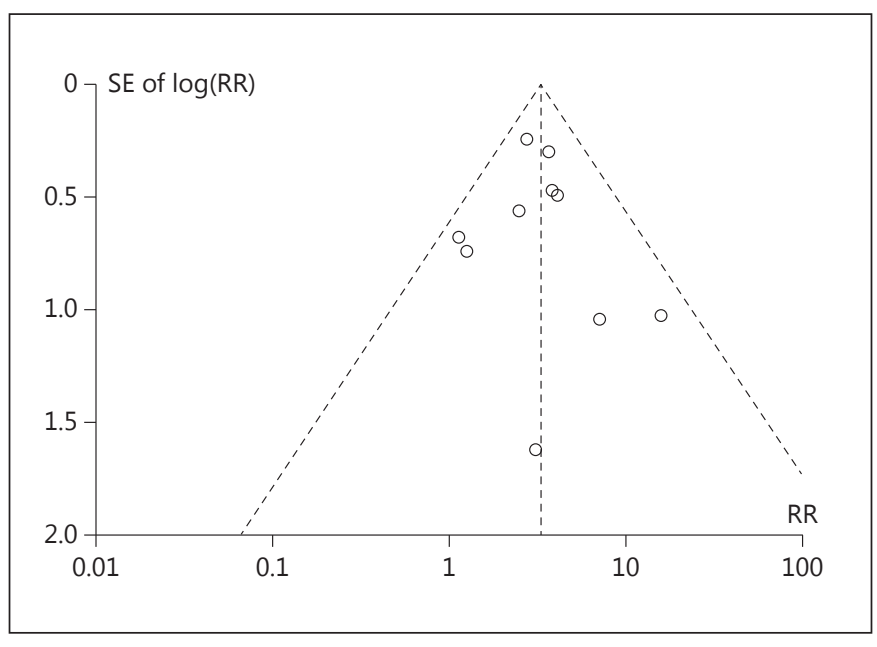

Fig. 4. Funnel plots for publication bias.

ed with ramucirumab. Our analysis of data demonstrated an increased risk of all-grade and high-grade proteinuria with ramucirumab-based treatment compared with control.

Angiogenesis is a crucial process in human development and growth. Pathologically, aberrant angiogenic mechanisms play a major role in cancer growth and are a necessary process for tumor metastasis [21, 22]. Binding of VEGF to its receptors (VEGFR-1, VEGFR-2) initiates 
an angiogenic signaling process with subsequent increased vascular permeability and endothelial cell proliferation [23]. VEGF pathway inhibition is an important anticancer strategy and ramucirumab - through VEGFR-2 targeting - suppresses the growth of many solid tumors [24].

Normal protein concentration in an adult should be less than $60 \mathrm{mg} / \mathrm{m}^{2} /$ day and proteinuria is said to be present when urinary protein excretion exceeds $300 \mathrm{mg} /$ day [25].

Proteinuria has been reported as a class effect with many VEGF-targeting agents, including bevacizumab and aflibercept as well as many VEGF-tyrosine kinase inhibitors [26-28]. The underlying mechanism is not completely understood. However, research has suggested that the inhibition of VEGF-dependent interactions between podocytes and glomerular endothelial cells may result in proteinuria through the disruption of the filtration barrier [29]. Another molecule that may be implicated in proteinuria secondary to antiangiogenic agents is the nephrin which is downregulated by VEGF pathway inhibition and this may lead to proteinuria [30].

A number of quantitative and qualitative tests are available for the assessment of urinary proteins. The most frequently used test is the urinalysis dipstick. However, it is sensitive for glomerular rather than tubular proteinuria and the degree of positivity roughly correlates with the heaviness of proteinuria [31]. However, due to a relatively high rate of false-positive results, whenever proteinuria is suspected by urine dipstick it should be confirmed through a 24-hour urinary protein assessment [32]. Alternatively, if timely collection of urine is not possible, protein/creatinine or albumin/creatinine ratios may be used instead [33].

With the progress of anticancer therapies, survival of cancer patients has improved and thus meticulous attention to long-term consequences of cancer treatment becomes more and more important. Proteinuria has been reported as a risk factor for both cardiovascular and renal disease and, thus, early detection and management of proteinuria secondary to antiangiogenic agents should be part of the management of cancer patients receiving these drugs [30, 34].

Many studies have demonstrated an important role for angiotensin-converting enzyme inhibitors (ACEIs) and angiotensin receptor blockers (ARBs) in control of proteinuric renal conditions [35]. To our knowledge, no interventional studies have been conducted to assess the role of these agents in VEGF inhibition-mediated proteinuria and thus evidence-based recommendations both in the preventive and therapeutic settings cannot be made. Nevertheless, many cases with antiangiogenic-related proteinuria in practice are given ACEIs and ARBs on an exploratory basis from the data of other proteinuric conditions. This practice has been supported also by an antiproteinuric effect of these agents in cases of renal transplantation treated with mTOR inhibitors [36]. Moreover, in an interesting preclinical study by Lankhorst et al. [37], combined endothelin receptor antagonism, ACEI and phosphodiesterase type-5 inhibition were effective in preventing angiogenesis inhibition-induced proteinuria. These preclinical data may provide a strong rationale for a randomized study for the use ACEIs or ARBs in the prevention and/or treatment of antiangiogenic-related proteinuria.

Another important consideration in this setting is the other toxicities commonly induced by antiangiogenic agents, particularly hypertension. Because ACEIs are considered the best treatments for hypertension associated with proteinuria, their use in patients with hypertension and proteinuria secondary to antiangiogenic agents may be very rational [38-40].

According to the manufacturer's recommendations, if grade 3-4 nonhematological toxicity occurs, dose interruption and/or reduction should be considered [41]. Thus, part of the management of proteinuria of ramucirumab may involve the adjustment of drug dosage as per the grade of the toxicity and the manufacturer's guidelines.

Despite the clear risk of all-grade and high-grade proteinuria experienced by ramucirumab-treated patients in our meta-analysis, the risk of renal impairment was not increased in the majority of included studies. This may be explained by the fact that in the setting of close monitoring in the included clinical trials, ramucirumab was stopped once significant proteinuria had developed. This may have prevented progression into frank renal impairment.

The results of our analysis have to be dealt with taking into consideration a number of limitations. The first limitation we see is the heterogeneity observed with regard to the type of solid tumors treated and the regimens used. Subgroup analyses have been conducted to try to overcome this limitation. The second limitation is the fact that this is a meta-analysis at the study level and not at the individual patient data level. Therefore, individual variables at the patient level (e.g. comorbidities predisposing to more proteinuria or renal impairment) were not elaborated in the analysis. 


\section{Conclusions}

Our meta-analysis has demonstrated that ramucirumab is associated with an increased risk of all-grade and high-grade proteinuria. Clinicians should be aware of these risks and perform regular specific follow-up for these toxicities.

\section{Disclosure Statement}

The authors have no conflicts of interest to declare. No funding was received for this study.

\section{References}

1 Lu D, Jimenez X, Zhang H, Bohlen P, Witte L, Zhu Z: Selection of high affinity human neutralizing antibodies to VEGFR2 from a large antibody phage display library for antiangiogenesis therapy. Int J Cancer 2002;97:393399.

2 Lu D, Shen J, Vil MD, Zhang H, Jimenez X, Bohlen P, Witte L, Zhu Z: Tailoring in vitro selection for a picomolar affinity human antibody directed against vascular endothelial growth factor receptor 2 for enhanced neutralizing activity. J Biol Chem 2003;278: 43496-43507.

- 3 Fontanella C, Ongaro E, Bolzonello S, Guardascione M, Fasola G, Aprile G: Clinical advances in the development of novel VEGFR2 inhibitors. Ann Transl Med 2014;2:123.

4 Wilke H, Muro K, Van Cutsem EV, et al: Ramucirumab plus paclitaxel versus placebo plus paclitaxel in patients with previously treated advanced gastric or gastro-oesophageal junction adenocarcinoma (RAINBOW): a double-blind, randomised phase 3 trial. Lancet Oncol 2014;15:1224-1235.

5 Fuchs CS, Tomasek J, Yong CJ, et al: Ramucirumab monotherapy for previously treated advanced gastric or gastro-oesophageal junction adenocarcinoma (REGARD): an international, randomised, multicentre, placebocontrolled, phase 3 trial. Lancet 2014;383:3139.

6 Abdel-Rahman, O: Targeting vascular endothelial growth factor (VEGF) pathway in gastric cancer: preclinical and clinical aspects. Crit Rev Oncol Hematol 2015;93:18-27.

7 Bozza C, Fontanella C, Buoro V, Mansutti M, Aprile G: Novel antiangiogenic drugs for the management of breast cancer: new approaches for an old issue? Exp Rev Clin Pharmacol 2015;8:251-265.

8 Aprile G, Rijavec E, Fontanella C, Rihawi K, Grossi F: Ramucirumab: preclinical research and clinical development. Onco Targets Ther 2014;7:1997.

-9 Moher D, Liberati A, Tetzlaff J, Altman DG; PRISMA Group: Preferred reporting items for systematic reviews and meta-analyses: the PRISMA statement. J Clin Epidemiol 2009; 62:1006-1012.
DerSimonian R, Laird N: Meta-analysis in clinical trials. Control Clin Trials 1986;7:177188.

11 Higgins JP, Thompson SG, Deeks JJ, Altman DG: Measuring inconsistency in meta-analyses. BMJ 2003;327:557-560.

12 Yardley DA, Richards PD, Reeves JA, et al: Final results of a phase 2 study of ramucirumab (RAM) plus erbulin (E) versus $\mathrm{E}$ in advanced metastatic breast cancer (MBC). Abstract 1035. J Clin Oncol 2014;32(suppl):S5.

13 Yoon HH, Bendell JC, Braiteh FS, et al: Ramucirumab (RAM) plus FOLFOX as front-line therapy $(\mathrm{Rx})$ for advanced gastric or esophageal adenocarcinoma (GE-AC): Randomized, double-blind, multicenter phase 2 trial. Abstract 4004. J Clin Oncol 2014;32(suppl):S5.

14 Doebele RC, Spigel D, Tehfe M, et al: Phase 2, randomized, open-label study of ramucirumab in combination with first-line pemetrexed and platinum chemotherapy in patients with nonsquamous, advanced/metastatic non-small cell lung cancer. Cancer 2015;121:883-892.

15 https://clinicaltrials.gov/ct2/show/results/ NCT01160744?term =ramucirumab\&rank= 38\&sect=X01256\#all (accessed March 31, 2015).

16 Zhu AX, Ryoo BY, Yen CJ, et al: Ramucirumab as second-line treatment in patients with advanced hepatocellular carcinoma following first-line therapy with sorafenib: results from the randomized phase III REACH trial. Ann Oncol 2014;25(suppl 5):v1-v41.

17 Garon EB, Ciuleanu TE, Arrieta O, et al: Ramucirumab plus docetaxel versus placebo plus docetaxel for second-line treatment of stage IV non-small-cell lung cancer after disease progression on platinum-based therapy (REVEL): a multicentre, double-blind, randomised phase 3 trial. Lancet 2014;384:665673.

18 Hussain M, Rathkopf DE, Liu G, et al: A phase II randomized study of cixutumumab (IMCA12:CIX) or ramucirumab (IMC-1121B: RAM) plus mitoxantrone (M) and prednisone $(\mathrm{P})$ in patients (patients) with metastatic castrate-resistant prostate cancer (mCRPC) following disease progression (PD) on docetaxel (DCT) therapy (abstract). J Clin Oncol 2012;30(suppl 5):97.
19 Mackey JR, Ramos-Vazquez M, Lipatov O, et al: Primary results of ROSE/TRIO-12, a randomized placebo-controlled phase III trial evaluating the addition of ramucirumab to first-line docetaxel chemotherapy in metastatic breast cancer. J Clin Oncol 2015;33:141148 .

20 Tabernero J, Cohn AL, Obermannova R, et al: RAISE: a randomized, double-blind, multicenter phase III study of irinotecan, folinic acid, and 5-fluorouracil (FOLFIRI) plus ramucirumab (RAM) or placebo (PBO) in patients (patients) with metastatic colorectal carcinoma (CRC) progressive during or following first-line combination therapy with bevacizumab (bev), oxaliplatin (ox), and a fluoropyrimidine (fp). J Clin Oncol 2015;16: 499-508.

21 Chung AS, Lee J, Ferrara N: Targeting the tumour vasculature: insights from physiological angiogenesis. Nat Rev Cancer 2010;10:505514

22 Abdel-Rahman O: Targeting vascular endothelial growth factor (VEGF) pathway in iodine-refractory differentiated thyroid carcinoma (DTC): from bench to bedside. Crit Rev Oncol Hematol 2015;94:45-54.

23 Kerbel RS: Tumor angiogenesis. N Engl J Med 2008;358:2039-2049.

24 Abdel-Rahman O: Vascular endothelial growth factor (VEGF) pathway and neuroendocrine neoplasms (NENs): prognostic and therapeutic considerations. Tumor Biol 2014; 35:10615-10625.

25 http://emedicine.medscape.com/article/ 238158-overview (accessed April 24, 2015).

26 Peng L, Zhao Q, Ye X, Zhou Y, Hu D, Zheng $S$ : Incidence and risk of proteinuria with aflibercept in cancer patients: a meta-analysis. PLoS One 2014;9:e111839.

27 Wu S, Kim C, Baer L, Zhu X: Bevacizumab increases risk for severe proteinuria in cancer patients. J Am Soc Nephrol 2010;21:13811389.

28 Baek S, Kim H, Lee J, et al: Renal adverse effects of sunitinib and its clinical significance: a single-center experience in Korea. Korean J Intern Med 2014;29:40-48. 
29 Eremina V, Sood M, Haigh J, Nagy A, Lajoie $G$, et al: Glomerular-specific alterations of VEGF-A expression lead to distinct congenital and acquired renal diseases. J Clin Invest 2003;111:707-716.

30 Izzedine H, Massard C, Spano JP, Goldwasser $F$, Khayat D, et al: VEGF signalling inhibitioninduced proteinuria: mechanisms, significance and management. Eur J Cancer 2010; 46:439-448.

-31 Larmour KE, Maxwell AP, Courtney AE: Improving early detection of chronic kidney disease. Practitioner 2015;259:19-23.

32 Lewis G, Maxwell AP: Timely diagnosis and treatment essential in glomerulonephritis. Practitioner 2015;259:13-17.

-33 Warady BA, Abraham AG, Schwartz GJ, Wong CS, Muñoz A, Betoko A, Furth S: Predictors of rapid progression of glomerular and nonglomerular kidney disease in children and adolescents: the Chronic Kidney Disease in Children (CKiD) cohort. Am J Kidney Dis 2015;65:878-888.

34 Bakris GL: Slowing nephropathy progression: focus on proteinuria reduction. Clin J Am Soc Nephrol 2008;3(suppl 1):S3-S10.

35 De Zeeuw D, Remuzzi G, Parving HH, Keane WF, Zhang Z, Shahinfar S, et al: Proteinuria, a target for renoprotection in patients with type 2 diabetic nephropathy: lessons from RENAAL. Kidney Int 2004;65: 2309-2320.

36 Hiremath S, Fergusson D, Doucette S, Mulay AV, Knoll GA: Renin angiotensin system blockade in kidney transplantation: a systematic review of the evidence. Am J Transplant 2007;7:2350-2360.

37 Lankhorst S, Kappers MH, van Esch JH, Smedts FM, Sleijfer S, Mathijssen RH, et al: Treatment of hypertension and renal injury induced by the angiogenesis inhibitor sunitinib: preclinical study. Hypertension 2014; 64:1282-1289.

38 Kidney Disease Outcomes Quality Initiative: $\mathrm{K} / \mathrm{DOQI}$ clinical practice guidelines on hypertension and antihypertensive agents in chronic kidney disease. Am J Kidney Dis 2004;43(suppl 1):S1-290.

39 Dincer M, Altundag K: Angiotensin-converting enzyme inhibitors for bevacizumab-induced hypertension. Ann Pharmacother 2006;40:2278-2279.

40 Abdel-Rahman O, Alorabi M: Use of angiotensin-converting enzyme inhibitors in the prophylaxis of anthracycline or trastuzumabrelated cardiac dysfunction: preclinical and clinical considerations. Expert Rev Anticancer Ther 2015;15:829-837.

41 http://pi.lilly.com/us/cyramza-pi.pdf (accessed April 1, 2015). 